\title{
Soya protein antigenicity and small intestinal motility in preruminant calves
}

\author{
C Duvaux-Ponter ${ }^{1}$, JP Lallès ${ }^{2}$, R Toullec ${ }^{2}$ \\ 1 INRA, station de Nutrition et Alimentation, INA-PG, 16, rue Claude-Bernard, 75231 Paris Cedex 05; \\ 2 INRA, laboratoire du Jeune Ruminant, 65, rue de Saint-Brieuc, 35042 Rennes Cedex, France
}

In 2 calf feeding trials using 2 batches of the same heated soya product (AHS1 and AHS2, in vitro antigenicity $\mathrm{Ag} \mathrm{7-8),} \mathrm{Lallès}$ and Toullec (unpublished results) showed that AHS1 had high in vivo antigenicity (plasma soya antibody titre $A b 7.8$ ) and low nitrogen digestibility (0.61) while AHS2 had low in vivo antigenicity (2.8) and higher nitrogen digestibility $(0.71)$. Since preruminant calves sensitive to soya protein develop digestive disturbances associated with gut motility disorders (Sissons et al, 1987 ), the effect of these 2 products on intestinal motility were studied.

After oral sensitization to soya, 3 calves were sensitive (Ab 5.7) and 3 were not (Ab 1.2). They were fitted with abomasal and distal ileal cannulae and duodenal electrodes. At intervals of 3-7 $d$ they received abomasal infusions of liquid test feeds in which protein was either provided by milk or AHS or non-antigenic soya concentrate ( $\mathrm{Ag}$ and $\mathrm{Ab} 0.0$; NASC) or milk plus untreated soya flour ( $\mathrm{Ag} \mathrm{12-13;} \mathrm{SBF}$ ). Motility and intestinal transit time (TT estimated by the arrival of phenol red at the ileal cannula) were recorded.

Preliminary results (table I) given as percentage of milk values (mean \pm SEM: TT, $187 \pm 40 \mathrm{~min}$; number of migrating myoelectric complexes per $h(M M C / h), 1.02 \pm$ 0.28 ; duration of first postprandial irregular spike activity (PPISA), $133 \pm 30.6 \mathrm{~min}$ ) showed that $\Pi T$ in insensitive calves was minimally affected by the soya diets. $T T$ in sensitive calves was highly reduced after SBF and AHS1 (often associated with diarrhoea) while $T T$ was reduced to a lesser extent after NASC and AHS2 (no diarrhoea).
These observations were supported by the motility results, mainly after SBF and AHS1 (increased $\mathrm{MMC} / \mathrm{h}$ and reduced PPISA in sensitive calves) and suggest that AHS2 had less effect in vivo than AHS1.

In conclusion, giving antigenic soya to sensitive calves led to drastic motility changes. Products with high in vitro antigenicity can behave differently in vivo and motility and transit measurements may be more effective in discriminating between these products.

Sissons JW, Pedersen HE, Duvaux C, Thurston SM, Starkey S, Wass JAH (1987) Food Allergy (Chandra RK, ed). Nutr Res Educ Fdn, St Johns, Newfoundland, 95-108

Table I. Mean (\% of milk values) for motility parameters in calves.

\begin{tabular}{|c|c|c|c|c|c|c|}
\hline \multirow{2}{*}{$\begin{array}{l}\text { Protein } \\
\text { source }\end{array}$} & \multicolumn{3}{|c|}{ Insensitive calves } & \multicolumn{3}{|c|}{ Sensitive catves } \\
\hline & $M M C / h$ & PPISA & $\pi$ & MMC/h & PPISA & $\pi$ \\
\hline SBF & 92 & 92 & $70^{\star \star}$ & 177 & $16^{\star \star a b}$ & $32^{\star \star}$ \\
\hline $\mathrm{ASH} 1$ & 126 & 103 & $81^{a}$ & $194^{* *}$ & $39^{* \star a c}$ & $40^{* *}$ \\
\hline $\mathrm{AHS} 2$ & $58^{*}$ & $145^{\star}$ & 93 & $140^{\star *}$ & $89^{\text {bd }}$ & $60^{*}$ \\
\hline NASC & $79^{\star \star \star \star *}$ & $76^{* * * *}$ & $103^{\star b}$ & $121^{*}$ & $64 \mathrm{~cd}$ & $60^{*}$ \\
\hline (SEM) & (8.2) & $(9.9)$ & $(5.1)$ & (16.8) & (8.3) & (6.2) \\
\hline
\end{tabular}

* 1 or 2 values only, "* different from milk values $(P<$ $0.05)$; a. o. c. d differences between means within columns $(P<0.05)$. 